\title{
Evaluasi Sistem Informasi Administrasi Terhadap Kualitas Pelayanan Dan Kinerja Program Studi
}

\author{
Febrianto Sabirin'1, Dewi Sulistiyarini' ${ }^{2}$ \\ 1rinakasaka@gmail.com, 2dhewysulis@gmail.com \\ IKIP PGRI Pontianak, Indonesia1, 2
}

Received: November 2020

Accepted: November 2020

Online Published: Desember 2020

\section{Abstract}

The administrative information system is a website-based information system that is used to assist the administrative activities of the Computer and Information Technology Education Program (P.TIK) of the IKIP PGRI Pontianak. The purpose of this study was to determine the service quality and performance of the P.TIK study program after implementing the study program administration information system. The method used in this research is a survey method with a descriptive evaluative research approach. The research sample consisted of 185 students of P.TIK IKIP PGRI Pontianak using purposive sampling technique by selecting students who had used the study program administration information system. The data collection tool used was a closed questionnaire with data analysis techniques using descriptive statistics. The results showed that the service quality and performance of the study program after using the administrative information system were in the very good category.

Keywords: administrative information systems, service quality, and performance

\begin{abstract}
Abstrak
Sistem informasi administrasi merupakan sistem informasi berbasis website yang digunakan untuk membantu kegiatan administrasi Program Studi Pendidikan Teknologi Informasi dan Komputer (P.TIK) IKIP PGRI Pontianak. Tujuan penelitian ini adalah untuk mengetahui kualitas pelayanan dan kinerja program studi P.TIK setelah menerapkan sistem informasi administrasi program studi. Metode yang digunakan dalam penelitian yaitu metode survey dengan jenis pendekatan penelitian deskriptif evaluatif. Sampel penelitian ini berjumlah 185 mahasiswa P.TIK IKIP PGRI Pontianak menggunakan teknik purposive sampling dengan memilih mahasiswa yang pernah menggunakan sistem informasi administrasi program studi. Alat pengumpul data yang digunakan adalah kusioner tertutup dengan teknik analisis data menggunakan statistik deskriptif. Hasil penelitian menunjukkan bahwa kualitas pelayanan dan kinerja program studi setelah menggunakan sistem informasi administrasi berada pada kategori sangat baik.
\end{abstract}

Kata Kunci: sistem informasi administrasi, kualitas pelayanan, dan kinerja

\section{PENDAHULUAN}

Penggunaan teknologi dalam dunia pendidikan diperlukan untuk meningkatkan standar kompetensi baik di lingkungan internal institusi maupun nasional. Berdasarkan Undang-Undang Nomor 11 Tahun 2019 tentang Sistem Nasional Ilmu Pengetahuan dan Teknologi disebutkan bahwa teknologi merupakan cara ataupun metode yang pemanfaatannya pada berbagai disiplin ilmu pengetahuan dapat berguna dalam memenuhi kebutuhan, kelangsungan dan peningkatan kualitas hidup manusia. Oleh 
karena itu, diperlukan suatu teknologi untuk meningkatkan pengelolaan informasi. Sistem informasi administrasi adalah kumpulan komponen kegiatan yang saling terhubung untuk mencapai tujuan tertentu (Supriadi \& Bachtiar, 2018). Hal tersebut sejalan dengan Irwanto \& Rahmatullah (2012) yang menyatakan bahwa informasi administratif memiliki nilai strategis sehingga perlu dilakukan pengelolaan terhadap suatu informasi administrasi secara berkelanjutan dan terorganisir.

Program studi Pendidikan Teknologi Informasi dan Komputer (P.TIK) IKIP PGRI Pontianak mempunyai peran yang sangat penting dalam menjembatani kegiatankegiatan mahasiswa selama melaksanakan perkuliahan. Penggunaan sistem informasi administrasi program studi dimaksudkan untuk membantu program studi dalam melaksanakan kegiatan administratif, meningkatkan kualitas pelayanan, dan kinerja program studi menjadi lebih baik (Sulistiyarini, Sabirin, \& Permana, 2019). Sistem informasi dianalisis, dirancang dan dikembangkan berdasarkan analisis kebutuhan pengguna. Cakupan kegiatan yang terdapat dalam sistem informasi administrasi program studi P.TIK IKIP PGRI Pontianak yaitu pemberkasan surat, jurnal mengajar dosen, dan pendaftaran pelaksanaan seminar dan skripsi mahasiswa (Sulistiyarini \& Sabirin, 2018). Penggunaan sistem informasi administrasi program studi berbasis website memberikan kemudahan bagi pengguna baik staf, dosen, mahasiswa maupun pimpinan program studi untuk mengevalusi kegiatan administratif yang dilakukan. Berdasarkan uji coba yang dilakukan diketahui bahwa sistem informasi administrasi program studi untuk program studi P.TIK IKIP PGRI Pontianak mendapatkan respon yang baik oleh calon pengguna sistem dan telah layak untuk digunakan (Sulistiyarini, Sabirin, \& Permana, 2019; Sabirin, Sulistiyarini, \& Zulkarnain, 2020).

Berdasarkan hasil pengujian dan respon pengguna yang menunjukkan hal yang positif, maka saat ini sistem infromasi administrasi berbasis website digunakan dan menggantikan sistem yang sebelumnya masih menggunakan sistem secara konvensional. Fungsi dari sistem informasi adalah meningkatkan efektivitas dan efisiensi pekerjaan dari pengguna (Martono, 2020). Untuk itulah sistem informasi adminsitrasi program studi diharapkan dapat meningkatkan kualitas pelayanan dan kinerja dari program studi P.TIK IKIP PGRI Pontianak. Pelayanan dapat diartikan sebagai usaha menolong, menyediakan segala apa yang diperlukan oleh orang lain (Sinambela, 2010). Bentuk pelayanan yang diberikan melalui sistem informasi administrasi Program Studi P.TIK IKIP PGRI Pontianak adalah menyediakan fasilitas untuk dosen, mahasiswa, staf, dan pimpinan program studi terkait dengan kegiatan administrasi program studi. Pelayanan untuk mahasiswa berupa permohonan surat izin, pengajuan pemeriksaan dokumen seminar dan skripsi, dan pendaftaran seminar dan skripsi. Pelayanan untuk staf adalah menyediakan sarana untuk pendataan surat masuk dan keluar, pembuatan surat izin, dan rekapitulasi jurnal dosen mengajar. Pelayanan untuk pimpinan program studi berupa laporan-laporan terkait kegiatan administrasi yang ada di Program Studi P.TIK. 
Selain diharapkan mampu meningkatkan kualitas pelayanan, penggunaan SIAP TIK juga diharapkan mampu meningkatkan kinerja dari Program Studi P.TIK IKI PGRI Pontianak. Kinerja seringkali diasosiasikan dengan prestasi yang berarti perilaku yang secara langsung berhubungan dengan aktivitas hasil kerja dan pencapaian tugas. Kinerja Program Studi P.TIK dapat dilihat dari efektivitas dan efisien yang berhasil dicapai dari sistem informasi yang digunakan (Mudjiati, 2008). Efektivitas dari sistem informasi administrasi Program Studi P.TIK IKIP PGRI Pontianak dapat dilihat dari output yang dihasilkan sesuai dengan input yang telah dimasukkan oleh pengguna. Sementara efisiensi dari SIAP TIK dapat dilihat melalui sumber daya yang dikeluarkan dalam menghasilkan output tersebut.

Dengan telah diterapkannya sistem inforamsi administrasi berbasis website pada Program Studi P.TIK IKIP PGRI Pontianak maka perlu dilakukan evaluasi untuk melihat dampak dari penggunaan sistem informasi adminsitrasi yang telah dibangun dan digunakan oleh Program Studi P.TIK IKIP PGRI Pontianak. Evaluasi merupakan kegiatan yang dilakukan untuk melihat keterlaksanaan suatu sistem menggunakan intrumen yang kemudian hasilnya dibandingkan dan diperoleh kesimpulan (Yunanda, 2009). Evaluasi penggunaan sistem informasi dilakukan untuk mengetahui permasalahan yang terjadi dalam penggunaan sistem, dan faktor keberhasilan pelaksanaan sistem informasi sejak dini. Sebagai contoh, berdasarkan penelitian Wahyuni \& Maita (2015), Sinaga \& Haryanto (2016), diketahui terdapat kesenjangan antara ekspektasi manajemen dan persepsi pengguna, selain itu kecukupan, kemampuan SDM, dan kualitas data mempengaruhi keberhasilan penggunaan sistem informasi. Permasalahan yang teridentifikasi tersebut selanjutnya dilakukan perbaikan dalam tiap prosesnya agar memenuhi kebutuhan pengguna. Di sisi lain, menurut penelitian Wiyati \& Sarja (2019) diketahui bahwa penggunaan sistem informasi sesuai dengan kebutuhan dan terdapat pengaruh yang signifikan antara variable kualitas, kualitas layanan, dan kepuasan pengguna. Oleh karena itu, penelitian ini bertujuan untuk mengetahui kualitas kinerja dan pelayanan Program Studi P.TIK setelah menerapkan sistem informasi administrasi berbasis website.

\section{METODE PENELITIAN}

Penelitian dilakukan dengan metode survei dan pendekatan penelitian deskriptif evaluatif. Evaluasi yaitu prosedur untuk mengukur suatu pekerjaan atau proyek dengan metode yang terpercaya (Muryadi, 2017). Penelitian tentang "evaluasi sistem informasi administrasi terhadap kualitas layanan dan kinerja program studi pendidikan teknologi informasi dan komputer IKIP PGRI Pontianak" menggunakan model evaluasi yaitu evaluasi sumatif. Model evaluasi sumatif dipilih karena evaluasi sumatif adalah evaluasi akhir suatu sistem (Purwanto, 2009: 28).

Variabel penelitian yaitu kualitas pelayanan dan kinerja program studi terhadap sistem informasi administrasi program studi. Indikator kualitas pelayanan yang diukur 
yaitu tangible, emphaty, reliability, responsiveness, dan assurance. Indikator kinerja yang diukur yaitu kuantitas, kualitas, dan ketepatan waktu. Sampel penelitian yaitu mahasiswa Program Studi P.TIK IKIP PGRI Pontianak dengan berjumlah 185 mahasiswa. Teknik pengambilan sampel menggunakan puposive sampling dengan penentuan sampel yaitu mahasiswa yang pernah menggunakan sistem informasi administrasi Program Studi P.TIK IKIP PGRI Pontianak.

Teknik pengumpulan data yang digunakan yaitu teknik pengukuran non-test dengan alat pengumpul data yaitu angket. Teknik analisis data yang digunakan yaitu statistik deskriptif. Hasil yang diperoleh selanjutkan akan disajikan dalam bentuk table dan grafik. Selanjutnya, data yang ada dikategorikan menggunakan lima kriteria sebagai berikut:

Tabel 1. Kategori Kecenderungan Variabel

\begin{tabular}{ccc}
\hline No & Rentang Skor & Kategori \\
\hline 1 & $\mathrm{X} \geq \mathrm{Mi}+1,8 \mathrm{Sbi}$ & Sangat baik \\
2 & $\mathrm{Mi}+0,6 \mathrm{SBi} \leq \mathrm{X}<\mathrm{Mi}+1,8 \mathrm{Sbi}$ & Baik \\
3 & $\mathrm{Mi}-0,6 \mathrm{SBi} \leq \mathrm{X}<\mathrm{Mi}+0,6 \mathrm{Sbi}$ & Cukup \\
4 & $\mathrm{Mi}-1,8 \mathrm{SBi} \leq \mathrm{X}<\mathrm{Mi}-0,6 \mathrm{Sbi}$ & Kurang \\
5 & $\mathrm{X}<\mathrm{Mi}-1,8 \mathrm{SBi}$ & Sangat kurang \\
\hline
\end{tabular}

\section{HASIL DAN PEMBAHASAN HASIL}

Sistem informasi administrasi adalah sistem informasi program studi yang mempermudah mahasiswa dalam melakukan pendaftaran seminar dan skripsi, serta mempermudah staf dalam mendokumentasikan administrasi program studi seperti surat menyurat. Penilaian terhadap sistem informasi administrasi dilakukan dengan memberikan kuesioner online kepada mahasiswa.

Kualitas pelayanan merupakan tolok ukur suatu keberhasilan pelayanan. Kualitas pelayanan dilakukan untuk mengukur kepuasan mahasiswa dalam menggunakan sistem informasi administrasi program studi. Berdasarkan kuesioner online yang telah dilakukan diperoleh hasil perhitungan statistik deskriptif sebagai berikut:

Tabel 2. Hasil Statistik Deskriptif Kualitas Pelayanan

\begin{tabular}{cccccccccc}
\hline N & Mean & Median & Modus & $\begin{array}{c}\text { St. } \\
\text { Deviasi }\end{array}$ & Skewness & Kurtosis & Min & Max & Range \\
\hline 185 & 104,32 & 103 & 102 & 6,758 & 0,018 & $-0,698$ & 87 & 116 & 29 \\
\hline
\end{tabular}


Berdasarkan tabel hasil statistik deskriptif, diketahui nilai rata-rata kualitas pelayanan berdasarkan persepsi mahasiswa yaitu sebesar 104,32; nilai median sebesar 103; modus sebesar 102; nilai standar deviasi sebesar 6,758; nilai skewness sebesar 0,018 yang berarti nilainya positif sehingga dapat diartikan bahwa distribusi data akan memiliki ekor atau kecondongan ke kanan; nilai kurtosis -0.698 yang berarti nilainya negatif sehingga dapat diartikan bahwa distribusi data akan memiliki ekor pendek; nilai range sebesar 29 yang berarti bahwa selisih antara nilai tertinggi dengan nilai terendah; nilai terendah sebesar 87; dan nilai tertinggi sebesar 116.

Berdasarkan pada kategori kecenderungan variabel, maka pengkategorian untuk variabel kualitas pelayanan adalah sebagai berikut:

Tabel 3. Kategori Kualitas Pelayanan

\begin{tabular}{cccc}
\hline Range & Kategori & Frekuensi & Frekuensi Relatif \\
\hline$X \geq 98,6$ & Sangat Baik & 150 & $81 \%$ \\
$81,2 \leq X<98,6$ & Baik & 35 & $19 \%$ \\
$63,8 \leq X<81,2$ & Cukup & 0 & 0 \\
$46,4 \leq X<63,8$ & Kurang & 0 & 0 \\
$X<46,4$ & Sangat Kurang & 0 & 0 \\
\hline
\end{tabular}

Berdasarkan gambar 2 diketahui terdapat $81 \%$ atau 150 mahasiswa menganggap bahwa kualitas pelayanan sangat baik, dan $19 \%$ atau 35 mahasiswa menganggap bahwa kualitas pelayanan baik. Hal ini menunjukkan bahwa secara umum kualitas pelayanan program studi setelah menggunakan sistem informasi administrasi masuk dalam kategori sangat baik.

Kinerja adalah hasil dari penggunaan sistem informasi administrasi program studi dan diukur pada waktu tertentu sesuai dengan ketentuan atau standar yang ditetapkan sebelumnya. Berdasarkan kuesioner online yang telah dilakukan diperoleh hasil perhitungan statistik deskriptif sebagai berikut:

Tabel 4. Hasil Statistik Deskriptif Kinerja

\begin{tabular}{cccccccccc}
\hline $\mathbf{N}$ & Mean & Median & Modus & $\begin{array}{c}\text { St. } \\
\text { Deviasi }\end{array}$ & Skewness & Kurtosis & Min & Max & Range \\
\hline 185 & 85,77 & 87 & 88 & 4,864 & $-1,558$ & 2,853 & 68 & 92 & 24 \\
\hline
\end{tabular}

Berdasarkan tabel hasil statistik deskriptif, diketahui nilai rata-rata kinerja sistem informasi administrasi program studi berdasarkan persepsi mahasiswa yaitu sebesar 85,77; nilai median sebesar 87; modus sebesar 88; nilai standar deviasi sebesar 4,864; nilai skewness sebesar -1,558 yang berarti nilainya negatif sehingga dapat diartikan bahwa distribusi data akan memiliki ekor atau kecondongan ke kiri; nilai kurtosis 2,853 yang berarti nilainya positif sehingga dapat diartikan bahwa distribusi data akan memiliki ekor panjang; nilai range sebesar 24 yang berarti bahwa selisih antara nilai tertinggi dengan nilai terendah; nilai terendah sebesar 68; dan nilai tertinggi sebesar 92. 
Berdasarkan pada kategori kecenderungan variablel, maka pengkategorian untuk variabel kinerja adalah sebagai berikut:

Table 5. Kategori Kinerja

\begin{tabular}{cccc}
\hline Range & Kategori & Frekuensi & Frekuensi Relatif \\
\hline$X \geq 78,2$ & Sangat Baik & 171 & $93 \%$ \\
$64,4 \leq X<78,2$ & Baik & 13 & $7 \%$ \\
$50,6 \leq X<64,4$ & Cukup & 0 & 0 \\
$36,8 \leq X<50,6$ & Kurang & 0 & 0 \\
$X<36,8$ & Sangat Kurang & 0 & 0 \\
\hline
\end{tabular}

Berdasarkan gambar 4 diketahui terdapat $93 \%$ atau 171 mahasiswa menganggap bahwa kinerja sangat baik, dan $7 \%$ atau 13 mahasiswa menganggap bahwa kinerja baik. Hal ini menunjukkan bahwa secara umum kinerja program studi setelah menggunakan sistem informasi administrasi masuk dalam kategori sangat baik.

\section{PEMBAHASAN}

Sistem informasi administrasi merupakan suatu upaya yang dilakukan oleh program studi untuk meningkatkan kualitas pelayanan. Kualitas pelayanan merupakan tolok ukur bagi program studi dalam memenuhi kebutuhan pengguna baik mahasiswa maupun dosen. Sistem informasi administrasi program studi P.TIK dikembangkan berdasarkan analisis dan perancangan yang telah dilakukan sebelumnya dengan pendekatan ADDIE (Sulistiyarini dkk, 2019). Pelayanan menggunakan sistem informasi akan meningkatkan kualitas suatu pelayanan yang berbanding lurus dengan kepuasaan pengguna baik mahasiswa maupun dosen yang ada dilingkungan program studi. Sistem informasi administrasi yang dirancang dan dikembangkan berdasarkan analisis pengguna akan mampu menghasilkan sistem yang baik dan memenuhi kebutuhan pengguna.

Sistem informasi administrasi telah diterapkan dan berikutnya dianalisis terkait evaluasi penggunaan sistem tersebut menggunakan kuesioner. Kuesioner diberikan kepada mahasiswa sebanyak 185 orang. Berdasarkan kuesioner tersebut diperoleh hasil rata-rata jawaban kualitas pelayanan program studi setelah menggunakan sistem informasi administrasi yaitu 104,32 dengan nilai median sebesar 103, modus sebesar 102, standar deviasi sebesar 6,758, skewness sebesar 0,018, kurtosis sebesar -0.698, range sebesar 29, nilai terendah sebesar 87, dan nilai tertinggi sebesar 116 . Kategori kualitas pelayanan yaitu sangat baik dengan frekuensi relatif sebesar $81 \%$ atau 150 orang, dan baik dengan frekuensi relatif sebesar $19 \%$ atau 35 orang.

Berdasarkan pembahasan diatas dapat disimpulkan bahwa kualitas pelayanan program studi setelah menerapkan sistem informasi administrasi pada kategori sangat baik dan penggunaanya dapat diteruskan. Hal ini sesuai dengan penelitian yang telah dilakukan oleh Suaryana, dkk (2016), Sahfitri (2014), Husda (2018), Rudini (2015) diketahui bahwa kualitas pelayanan memiliki pengaruh terhadap kepuasan pengguna sistem informasi dan dapat memberikan umpan balik kepada pimpinan untuk tindakan 
evaluasi. Tingginya skor sistem informasi administrasi program studi dikarenakan sistem informasi administrasi Program Studi P.TIK mampu memberikan data dengan akurat, mempunyai tampilan yang mudah dipahami, dan mampu memberikan respon yang cepat, selain itu sistem informasi administrasi juga menyediakan layanan yang membantu mahasiswa apabila mengalami kesulitan dan telah staf yang mengoperasikan sistem informasi administrasi telah dibekali pengetahuan yang cukup mumpuni dalam menjawab pertanyaan dari mahasiswa. Hasil penelitian ini sesuai dengan penelitian yang dilakukan Utami (2014) dan Lusiana, dkk (2020) yang menyatakan bahwa aspek-aspek seperti kehandalan, respon, keakuratan, empati, dan aspek-aspek yang dapat dilihat oleh pengguna akan mempengaruhi kepuasan pengguna.

Kinerja merupakan penilaian terhadap usaha maupun kemampuan seseorang dalam menjalankan fungsinya. Kinerja menurut Lubis, dkk (2019) merupakan hasil yang diperoleh berdasarkan pengukuran dalam periode waktu tertentu menggunakan ketentuan ataupun kesepakatan yang telah ditetapkan sebelumnya. Penilaian kinerja dilakukan untuk mengevaluasi usaha yang telah dilakukan, melihat keberhasilan dan kekurangan, serta sebagai bahan masukan untuk memperbaikinya.

Program studi P.TIK melakukan penilaian terhadap kinerja setelah menerapkan sistem informasi administrasi program studi. Penilaian dilakukan untuk melihat tanggapan pengguna yaitu mahasiswa terhadap kinerja sistem informasi administrasi apakah sangat baik, baik, cukup, kurang atau sangat kurang. Berdasarkan penilaian yang dilakukan menggunakan kuesioner kepada 185 orang mahasiswa diperoleh hasil ratarata jawaban kinerja program studi setelah menggunakan sistem informasi administrasi yaitu 85,77 dengan nilai median sebesar 87 , modus sebesar 88 , standar deviasi sebesar 4,864 skewness sebesar -0,1558, kurtosis sebesar 2,853, range sebesar 24, nilai terendah sebesar 68, dan nilai tertinggi sebesar 92. Kategori kinerja yaitu sangat baik dengan frekuensi relatif sebesar $93 \%$ atau 171 orang, dan baik dengan frekuensi relatif sebesar $7 \%$ atau 13 orang.

Berdasarkan pembahasan diatas dapat disimpulkan bahwa kinerja program studi setelah menerapkan sistem informasi administrasi pada kategori sangat baik dan penggunaanya dapat diteruskan. Hal ini sesuai dengan penelitian yang telah dilakukan oleh Khaidir \& Susanti (2015), Rijayana \& Paradita (2014) bahwa faktor utama yang mempengaruhi kinerja suatu sistem adalah kepuasan pengguna dan kinerja sistem informasi yang sangat baik dapat memenuhi kebutuhan pengguna. Kinerja Program Studi P.TIK berada pada kategori sangat baik setelah menggunakan sistem informasi administrasi dikarenakan output yang dihasilkan menggunakan sistem informasi administrasi dapat diberikan lebih cepat daripada menggunakan sistem konvensional, selain itu kelengkapan yang diperlukan untuk mengurus kegiatan administrasi telah tersimpan di dalam sistem informasi administrasi sehingga memudahkan mahasiswa dalam melengkapi persyaratan yang diperlukan dimanapun dan kapanpun. Hal ini sesuai dengan penelitian yang dilakukan oleh Sain, Sari, \& Arif (2018) dan Al Gheffirea, dkk (2019) yang menyatakan bahwa sistem informasi berbasis website dapat mendukung proses input dan output yang cepat dan akurat. 


\section{SIMPULAN}

Kualitas pelayanan dan kinerja Program Studi P.TIK IKIP PGRI Pontianaksetelah menggunakan sistem informasi administrasi berbasis website berada pada kategori sangat baik. Faktor yang mempengaruhi kualitas pelayanan program studi adalah tangible, emphaty, reliability, responsiveness, dan assurance. Faktor yang mempengaruhi kinerja program studi P.TIK adalah kuantitas, kualitas, dan ketepatan waktu dalam memproses kegiatan-kegiatan administrasi di Program Studi P.TIK IKIP PGRI Pontianak.

\section{UCAPAN TERIMA KASIH}

Ucapan terima kasih kepada LPPM IKIP PGRI Pontianak yang telah memberi bantuan dana untuk melaksanakan penelitian tahun 2020. Terimakasih kepada program studi P.TIK IKIP PGRI Pontianak yang telah bersedia memfasilitasi dan mendukung penelitian hingga selesai.

\section{DAFTAR PUSTAKA}

Al Gheffira, Inayah, Z.M., Teguh, R., \& Oktavianty, D. (2019). Sistem Informasi Manajemen Proyek Berbasis Website pada PT. AKM. Jurnal Teknik Informatika dan Sistem Informasi. Volume 6, No. 1. Hal 62-71. https://doi.org/10.35957/jatisi.v6i1.160

Husda, N. E. (2018). Analisa Kualitas Pelayanan Sistem Informasi Akademik Terhadap Kepuasan Pengguna Sistem Di STMIK Putera Batam. Computer Based Information Sistem Journal. Volume 1, Nomor 1. Hal 1-12. http://ejournal.upbatam.ac.id/index.php/cbis/article/view/349

Irawanto \& Rahmatullah. (2012). Implementasi Sistem Informasi Administrasi Kependudukan (SIAK) di Dinas Kependudukan dan Pencatatan Sipil Kota Banjarmasi. Junal Al’Ulum. Volume 54, Nomor 2. Hal 1-10. https://ojs.uniskabjm.ac.id/index.php/ULUM/article/view/400

Khaidir, K., \& Susanti, N. (2015). Analisis Faktor- faktor Yang Mempengaruhi Kinerja Sistem Informasi Akuntansi Pada Bank Rakyat Indonesia Kantor Cabang Bengkulu. Ekombis Review, Volume 3, Nomor 2. https://doi.org/10.37676/ekombis.v3i2.141

Lubis, Y., Hermanto, B., \& Edison, E. (2018). Manajemen dan Riset Sumber Daya Manusia. Bandung: Alfabeta.

Lusiana, Pasda, S., Mustari, Said, M.I., \& Hasan, M. (2020). Pengaruh Reliability, Responsiveness, Assurance, Empathy dan Tangibles Terhadap Kepuasan Konsumen GrabBike. Jurnal Ekonomi dan Pendidikan, Volume 3, No. 2. Hal 34-40. https://doi.org/10.26858/jekpend.v3i2.14307

Martono. (2020). Pengembangan dan Implementasi Sistem Informasi Sumber Daya Manusia. Processor: Jurnal Ilmiah Sistem Informasi, Teknologi Informasi, dan 
Sistem Komputer, Volume 15, No. 1, Hal 43-54. https://doi.org/10.33998/processor.2020.15.1.792

Mudjiati, J. (2008). Studi Pengaruh Penggunaan Sistem Informasi Terhadap Kinerja Karyawan Fakultas Ekonomi Universitas Diponegoro Semarang. Diambil dari http://eprints.undip.ac.id/17986/1/JOHANNA MUDJIATI.pdf.

Muryadi, A. D. (2017). Mode Evaluasi Program Dalam Penelitian Evaluasi. Jurnal Ilmiah $\begin{array}{llllll}\text { Penjas, } & \text { Vol. } & 3, & \text { No. } & 1 . & \text { Hal }\end{array}$

http://ejournal.utp.ac.id/index.php//IP/article/view/538

Purwanto. (2009). Evaluasi Hasil Belajar. Yogyakarta: Pustaka Pelajar.

Republik Indonesia. (2019). Undang-Undang Nomor 11 Tahun 2019 Tentang Sistem Nasional Ilmu Pengetahuan dan Teknologi. Dewan Perwakilan Rakyat: Jakarta.

Rijayana, I. \& Paradita, N. (2014). Analisis Kinerja Sistem Informasi Menggunakan Metode

Balanced Scorecard. Jurnal Ilmiah Teknologi Informasi Terapan. Volume 1, Nomor

1. Hal 52-55. https://doi.org/10.33197/jitter.vol1.iss1.2014.47

Rudini, A. (2015). Pengaruh Kualitas Sistem, Kualitas Informasi dan Kualitas Pelayanan SIA Terhadap Kepuasaan Mahasiswa. Jurnal Terapan manajemen dan Bisnis. Volume 1, Nomor 1. Hal 39-49. http://dx.doi.org/10.33772/jumbo.v4i1.12325

Sahfitri, V. (2014). Pengukuran Kualitas Layanan Sistem Informasi Menggunakan Servqual Methode. Jurnal Ilmiah Matrik. Volume 16, Nomor 2. Hal 105-114. http://jurnal.binadarma.ac.id/index.php/jurnalmatrik/article/view/243

Sinaga, E., \& Haryanto. (2016). Evaluasi Penerapan Sistem Informasi Puskesmas di Kabupaten Sleman. Journal of Information Systems for Public Health. Volume 1, Nomor 1. Hal 44-51. https://journal.ugm.ac.id/iisph/article/view/6042

Sinambela, Lijan Poltak. (2010). Reformasi Pelayanan Publik: Teori, Kebijakan, dan Implementasi. Jakarta: Pt Bumi Aksara.

Suaryana, I.G.N.A., Damayanthi, I.G.A.E., \& Merkusiwati, N.K.L.A. (2016). Kualitas dan Kepuasan Pengguna Terhadap Sistem Informasi Akademik Berbasis Web. Jurnal Ilmiah Akuntansi dan Bisnis. Volume 11, Nomor 2. Hal 84-90. https://doi.org/10.24843/JIAB.2016.v11.i02.p03

Sabirin, F., Sulistiyarini, D., \& Zulkarnain. (2020). Pengembangan Sistem Informasi Seminar dan Skripsi Mahasiswa. Edumatic: Jurnal Pendidikan Informatika. Volume 4, Nomor $1 . \quad$ Hal $\quad$ 73-82. journal.hamzanwadi.ac.id/index.php/edumatic/issue/view/230

Sulistiyarini, D., Sabirin, F., \& Permana, R. (2019). Pengembangan Sistem Informasi Administrasi Program Studi. Jurnal Pendidikan Informatika dan Sains, Volume 8, Nomor 2. Hal 153-162. http://dx.doi.org/10.31571/saintek.v8i2.1229

Sulistiyarini, D. \& Sabirin, F. (2018). Analisis Perancangan Sistem Informasi Administrasi Program Studi Pendidikan Teknologi Informasi dan Komunikasi. Jurnal Penelitian 
dan Pengembangan Sains dan Humaniora. Volume 2, Nomor 1. Hal 22-29. http://dx.doi.org/10.23887/jppsh.v2i1.14006

Supriadi, B., \& Bachtiar, L. (2018). Sistem Informsi Administrasi Pada Organisasi Himpunan Mahasiswa Islam Cabang Sampit Berbasis Web. Jurnal Penelitian Dosen FIKOM (UNDA). Volume 8, Nomor 1. Hal 1-7. http://jurnal.unda.ac.id/index.php/Jpdf/article/view/99

Utami, H. Y. (2014). Pengaruh Tangible, Empathy, Reliability, Responsiveness dan Assurance Terhadap Loyalitas Pelanggan Berbelanja Pada Toko Tita di Lubuk Buaya Kota Padang. Economica: Journala of Economic and Economic Education. Volume 3, No. 1. Hal 64-70. https://doi.org/10.22202/economica.2014.v3.i1.237

Wahyuni, V., \& Maita, I. (2015). Evaluasi Sisem Informasi Manajemen Rumah Sakit (SIMRS) Menggunakan Metode Unified Theory Of Acceptance And Use of Technology (UTAUT). Jurnal Rekayasa dan Manajemen Sistem Informasi. Volume 1, Nomor 1. Hal 55-61. http://dx.doi.org/10.24014/rmsi.v1i1.1306

Wiyati, R. K., \& Sarja, N.L.A.K.Y. (2019). Evaluasi Penerapan Sistem Informasi Absensi Online DEngan Hot Fit Model. Jurnal teknologi Informasi dan Komputer. Volume 5, Nomor 1. Hal 1-9. http://dx.doi.org/10.36002/jutik.v5i1.631

Yunanda, M. (2009). Evaluasi Pendidikan. Jakarta: Balai Pustaka.

Zain, A.S., Sari, E.M., \& Arif, M. (2018). Pengembangan Sistem Informasi Penerimaan Siswa Baru Berbasis Web di SMA 1 Annuqayah Sumenep. Jurnal Ilmiah Edutic. Volume 4, No. 2. Hal 53-62. https://doi.org/10.21107/edutic.v4i2.3914 